\title{
Suppression of Leaf Scald Symptom in Plum by Oxytetracycline Injection*
}

\author{
C. J. Chang**, C. E. Yonce*** and D. GardneR****
}

\begin{abstract}
Oxytetracycline (OTC) suppressed leaf scald symptoms in plum following trunk injection. Tools required were a cordless drill, a $28 / 163 \mathrm{~cm}$ drill bit, a hammer and J. J. Mauget's OTC capsules. Two injection schedules, one in late April or early May and the other in mid October, were selected for the best effect. Two capsules, each containing $0.16 \mathrm{~g}$ of OTC in $4 \mathrm{ml}$ solution were injected into each tree each time and two capsules of carrier solution were injected in control trees. After the first, third, and fifth injection in April, 1984, May, 1985 and May, 1986, respectively, OTC caused 61.5-100\%, 73.3-100\%, and 76.9$100 \%$ symptoms suppression recorded in August, 1984, 1985, and 1986, respectively. In May, 1985, after the second injection was administered in October, 1984, treated trees showed much less twig dieback than control trees.
\end{abstract}

(Received January 29, 1987)

Key words : phony peach, oxytetracycline chemotherapy.

\section{Introduction}

Plum leaf scald (PLS) is a disease caused by a xylem-limited bacterium. The disease was first described in 1935 in Argentina ${ }^{7)}$. In the United States, PLS was reported in $1977^{4)}$ and caused a serious problem on plums in the Southeastern area. In 1981, the bacterium was independently isolated and cultured in cell-free medium by Davis et al. ${ }^{3)}$ and Wells et al. ${ }^{12)}$. In vitro, the bacterium has shown to be very susceptible to penicillin and tetracycline. The minimum inhibitory concentrations of the above two antibiotics were $6.25 \mu \mathrm{g} / \mathrm{ml}$ and $1.56 \mu \mathrm{g} / \mathrm{ml}$, respectively ${ }^{1)}$. In vivo, however, no chemical control method has been studied and recommended for the growers. The disease causes tremendous losses in the plum industry. Besides, the same bacterium can cause phony disease of peach ${ }^{13}$. An effective chemical control of the plum leaf scald disease not only may help the plum industry, but may reduce the phony peach incidence. We report herein the effective suppression of leaf scald symptoms in plum by oxytetracycline injection.

\footnotetext{
* Supported in part by the U. S. Hatch and Georgia State Funds.

** Department of Plant Pathology, University of Georgia, Georgia Experiment Station, Experiment, GA 30212.

*** USDA, Southeastern Fruit and Tree Nut Laboratory, Byron, GA 31008.

**** Consultant, 38 Pointer Place, Savannah, GA 31419.
} 


\section{Materials and Methods}

Diseased trees. A total of nine 7-year old plum trees (Prunus salicina L.) showing leaf scald symptoms for the past three years located at Byron, GA were selected for injection. Randomly selected, six trees were injected with oxytetracycline and three with carrier as controls. The average trunk circumference was $35 \mathrm{~cm}$, ranging from 31.2 to $40.1 \mathrm{~cm}$.

Oxytetracycline $(\mathrm{OTC})$ and tree injection. Oxytetracycline capsules manufactured by J. J. Mauget Co. of Fairbank, CA were used. Each capsule contained $0.16 \mathrm{~g}$ of OTC in $4 \mathrm{ml}$ solution. Holes $(28 / 163 \mathrm{~cm})$ were drilled into trees with a cordless drill (Black \& Decker) about $10-15 \mathrm{~cm}$ above the ground. The hole depths varied among the trees. Generally, the drill was stopped when the white, living xylem tissue debris was seen in the drill bit. A tube was then inserted into the hole and a pressurized capsule containing OTC or carrier was then punctured into the tube by a hammer. Two capsules, for a total of $0.32 \mathrm{~g}$ OTC, were injected into each treated tree using one capsule in each side. Two capsules of the carrier solution were injected into each control tree. The capsules were disconnected and the uptake of the solutions were recorded $24 \mathrm{hrs}$ after injection. Injections were applied to each tree on the following dates : 27 April, 1984, 12 October, 1984, 10 May, 1985, 30 September, 1985, and 13 May, 1986.

Suppression of scald symptom. In August of 1984, 1985, and 1986, the efficacy of the OTC for suppression of scald symptom in plums was recorded by counting the total numbers of branches showing no leaf scald symptom. These numbers were then used to measure the percent suppression.

\section{Results}

\section{Uptake of the oxytetracycline}

Two to several hours were required for a tree to absorb $4 \mathrm{ml}$ of solution. Capsules were disconnected $24 \mathrm{hr}$ after injection, or otherwise as indicated. The uptake rates were almost $100 \%$, except one was $75 \%$ and the other $50 \%$.

\section{Toxicity of oxytetracycline to plum trees}

Two trees in our first injection developed a burning effect on part of the tree by OTC. The burning effect was described as the color of the branches including twings and leaves turned black after the OTC injection. No toxicity effect of OTC was recorded in the other four injections.

\section{Suppression of leaf scald symptoms}

It was evident that oxytetracycline effectively suppressed the symptom development (Table 1). The treated trees exhibited 61.5-100\%, 73.3-100\%, and 76.9-100\% symptom suppression after one, three, and five injections, respectively, whereas no suppression at all was shown in the control trees. On August 2, 1984, the control trees were turning brown and dying, whereas the treated trees were a healthy green color. The sup- 
Table 1. Percent suppression of leaf scald symptom in plum by oxytetracycline injection over a period of three years

\begin{tabular}{|c|c|c|c|c|c|}
\hline \multirow{2}{*}{ Tree \# } & \multirow{2}{*}{$\begin{array}{c}\text { Tetracycline }(\mathrm{T}) \\
\text { or } \\
\text { Control }(\mathrm{C})\end{array}$} & \multirow{2}{*}{$\begin{array}{l}\text { Number of } \\
\text { branches } \\
\text { per tree }\end{array}$} & \multicolumn{3}{|c|}{ Percent suppression $(\%)^{a}$} \\
\hline & & & 1984 & 1985 & 1986 \\
\hline 23 & $\mathrm{~T}$ & 15 & 66.7 & 73.3 & 80 \\
\hline 24 & $\mathrm{~T}$ & 13 & 92.3 & 92.3 & 92.3 \\
\hline 26 & $\mathrm{C}$ & 10 & - b) $^{\text {b) }}$ & - & - \\
\hline 27 & $\mathrm{~T}$ & $4^{c)}$ & 100 & 100 & 100 \\
\hline 28 & $\mathrm{~T}$ & 13 & 61.5 & 76.9 & 76.9 \\
\hline 29 & $\mathrm{C}$ & 7 & 0 & 0 & 0 \\
\hline 30 & $\mathrm{~T}$ & $8^{d)}$ & 75.0 & 75 & 100 \\
\hline 31 & $\mathrm{~T}$ & 9 & 100 & 100 & 100 \\
\hline 32 & $\mathrm{C}$ & 6 & 0 & 0 & 0 \\
\hline
\end{tabular}

a) Percent suppression = number of branches showing no leaf scald symptom divided by numbers of total branches.

b) Tree $\$ 26$ developed early defoliation and more red leaves without apparent scald symptom

c) Tree $\$ 27,3 / 4(75 \%)$ branches were burned due to toxicity.

d) Tree $\# 30,4 / 8$ (50\%) branches were burned due to toxicity.

pressive effect of OTC after two injections is shown in Fig. 1A \& B, where the treated trees showed less dieback compared with the control trees.

\section{Discussion}

For the first time we have demonstrated from a field study that oxytetracycline is able to suppress the leaf scald symptoms through tree injection. Two capsules containing $0.32 \mathrm{~g}$ of OTC in $8 \mathrm{ml}$ solution are enough for $61.5-100 \%$ suppresion in treated trees. The symptom suppression rates increased as the injection times increased (Table 1). Tools required for injection are a cordless drill (Black \& Decker), an 28/163 $\mathrm{cm}$ drill bit and a hammer in addition to the J. J. Mauget's OTC capsules. Whether it is economically applicable has not been analyzed.

In vitro, tetracycline is very inhibitory to the growth of several plant pathogenic $\mathrm{XLB}^{11}$. Among twelve antibiotics tested, tetracycline was the most potent in inhibition of XLB growth. The minimum inhibitory concentration (MIC) of tetracycline to plum leaf scald bacterium was $1.56 \mu \mathrm{g} / \mathrm{ml}$, whereas that of penicillin, chloramphenicol, erythromycin and ampicillin was $6.25,3.13,6.25$, and $12.5 \mu \mathrm{g} / \mathrm{ml}$, respectively. Symptom suppression results obtained from in vivo tests demonstrate the efficacy of tetracycline for potential application for control of plant diseases caused by XLB.

Tetracycline has been used for the symptom suppression of grape vines that exhibited Pierce's disease symptoms ${ }^{5}$ and for many other diseases caused by mycoplasmalike organisms ${ }^{6,9,10)}$. Hopkins and Mortensen ${ }^{5)}$ treated eight-year-old grapevines by soil drenching with 8 liters of a $50 \mu \mathrm{g} / \mathrm{ml}$ tetracycline solution twice-weekly for about 4 months. The remission of existing symptoms started approximately 40 days after the 

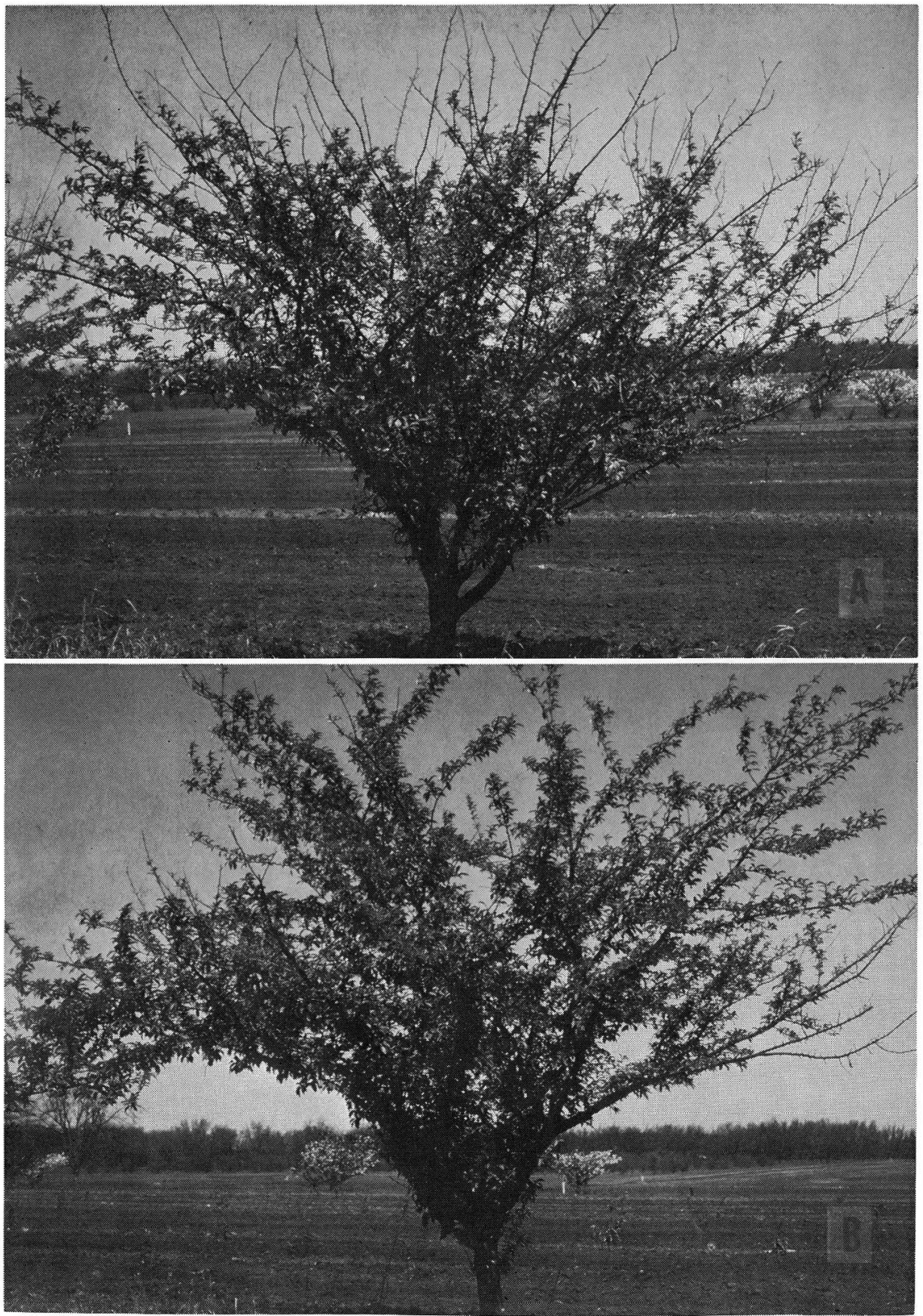

Fig. 1. Control tree (A) showing extensive twig dieback contrasted with oxytetracycline-treated tree (B) showing much less twig dieback, 10 May 1985.

first drencing, which amounted to about $4.8 \mathrm{~g}$ of tetracycline that was applied. This is 15 -fold more tetracycline than the $0.32 \mathrm{~g}$ used to inject each plum tree. Also, only 
two injections per year were required for symptom suppression as compared to twiceweekly for a period of 4 months by soil drenching.

Two injection times, one in late April/early May and the other in late September/ early October, were selected in order to obtain the best effect. Plum leaves are fully expanded and most physiologically active in late April/early May when the best uptake of the solution is expected. The bacterial population, according to our previous study, is at its lowest in April and $\mathrm{May}^{2}$. Therefore, we would be able to apply the minimum amount of OTC to diminish the number of bacteria. No other injection is needed until after harvest in October. The residue of OTC in plant tissue two to three months after injection is usually nondetectable ${ }^{8,11}$. For example, in the determination of OTC level in 482 coconut fruits, $\mathrm{McCoy}^{8}$ reported only 5 had detectable levels of OTC in coconut milk, all less than $0.3 \mu \mathrm{g} / \mathrm{ml}$. Nineteen had trace amounts of OTC $(<0.2 \mu \mathrm{g} /$ $\mathrm{ml}$ ) in milk. All other coconut milk readings were zero. Of 202 coconuts from which meat samples were assayed, 25 had measurable OTC levels, most of them less than 1.0 $\mu \mathrm{g} / \mathrm{g}$, although one did contain $2.6 \mu \mathrm{g} / \mathrm{g}$ of meat. Twenty had less than $0.3 \mu \mathrm{g} / \mathrm{g}$ in meat, 150 had not activity in the meat. The persistence values of OTC in coconut foliage indicate a half-life of about 2 weeks ${ }^{8}$. The half-life of $\mathrm{OTC}-\mathrm{HCl}$ in aster is about 3-4 days as reported by Sinha and Peterson ${ }^{11}$. The contamination of OTC in fruit would not be a problem for the consumers. The October injection, performed after harvest, was intended to reduce the number of bacterium that survived the April or May injection.

The tree injection technique developed by J. J. Mauget Co. is easy and effective. The tree injection has the advantage of eliminating air pollution generally caused by spraying. With the high uptake rate and safe and simple application technique, we believe it can be used for other tree treatment, such as systemic pesticides which are now applied by tree spraying.

\section{Literature cited}

1. Chang, C. J. and Schaad, N. W. (1982). Phytopathology $72: 1006$.

2. Chang, C. J. and Yonce, C. (1984). Ibid. $74: 879$.

3. Davis, J. M., French, W. J. and Schaad, N. W. (1981). Curr. Microbiol. 6 : 309-314.

4. French, W. J., Christis, R. G. and Stassi, D. L. (1977). Phytopathology $67: 945-948$.

5. Hopkins, D. L. and Mortensen, J. A. (1971). Disease Reporter 55 : 610-612.

6. Kirkpatrick, H. C., Lowe, S. K. and Nyland, G. (1975). Phytopathology $65: 864-870$.

7. Kitajima, E. W., Bakarcic, M. and Fernandez-valiela, M. V. (1975). Ibid. 65:476-479.

8. McCoy, R. E. (1976). Ibid. $66: 1038-1042$.

9. Nyland, G. (1971). Ibid. $61: 904$.

10. Rosenberger, D. A. and Jones, A. L. (1977). Ibid. $67: 277-282$.

11. Sinha, R. C. and Peterson, E. A. (1972). Ibid. $62: 377-383$.

12. Wells, J. M., Raju, B. C., Nyland, G. and Lowe, S. K. (1981). Appl. Environ, Microbiol. 42 : 357363.

13. Wells, J. M., Raju, B. C., Thompson, J. M. and Lowe, S. K. (1981). Phytopathology 71 : 11561161.

和 文 摘 要

C. J. ChANG・C. E. YonCE・D. GARDNER：オキシテトラサイクリンの注入によるスモモ葉烵病（仮称）の 


\section{発病抑制}

スモモの葉焼病はオキシテトラサイクリン（OTC）の樹幹注入により抑制された。作業にはコード無ドリ ル，28/163 cm ドリル刃，金ヅチおよび OTC カプセルを必要とした。 4 月下旬又は 5 月上旬に 1 回目， 10 月中旬に 2 回目の注入が最も効果的であった。それぞれ $0.16 \mathrm{~g}$ の OTC を含む $4 \mathrm{ml}$ の溶液の入ったカプセ ル 2 個分を各時期に各樹に注入し，対照樹にはキャリア液のみをそれぞれ注入した。1984年 4 月，1985年 5 月 および1986年 5 月にそれぞれ 1 回目，3 回目抢よび 5 回目の注入を行ない，1984，1985帖よび1986年の各 8 月 に調査した結果，OTC による発病抑制はそれぞれ61.5-100\%，73.3-100\%扔よび76.9-100\%であった。1984 年10月に 2 回目の注入を行なった樹では翌年 5 月には対照樹に比べて小枝の枯死が格段に少なかった。 